\title{
Outbreaks and risks of infectious spleen and kidney necrosis virus disease in freshwater ornamental fishes
}

\author{
Joon Bum Jeong ${ }^{1}$, Ho Yeoul Kim ${ }^{1}$, Lyu Jin Jun ${ }^{1}$, Ji Hyo Lyu ${ }^{1}$, Nam Gyu Park ${ }^{2}$, \\ Joong Kyun Kim², Hyun Do Jeong ${ }^{1, *}$
}

${ }^{1}$ Department of Aquatic Life Medicine, and ${ }^{2}$ Department of Biotechnology and Bioengineering, Pukyong National University, 599-1 Dae Yeon Dong, Nam Ku, Busan 608-737, South Korea

\begin{abstract}
We examined the distribution of iridoviruses in 10 freshwater ornamental fish species hatched in Korea and imported from other Asian countries using both 1-step and 2-step polymerase chain reation (PCR). None of the 10 fish species analyzed were free of iridovirus as shown by 2-step PCR positive results, and 3 species yielded 1-step PCR positive results with associated mortality. Cloned PCR amplicons of the adenosine triphosphatase (ATPase) and major capsid protein (MCP) genes in genomic DNA of iridovirus showed the same nucleotide sequences as that of infectious spleen and kidney necrosis virus (ISKNV) isolated from the mandarinfish Siniperca chuatsi. These results indicate the presence of ISKNV disease in various ornamental fish as new host species and that the disease is widespread throughout different Asian countries including Korea, Singapore and China. Such infections were either clinical with associated mortality (and 1-step PCR positive) or asymptomatic in fish that were externally healthy (and only positive in 2-step PCR). Molecular analyses of the K2 region performed on iridovirus samples isolated from freshwater ornamental fishes revealed deletion/insertion of repetitive sequences of various lengths (42 to $339 \mathrm{bp}$ ), depending on the ISKNV isolates, without substitutions. Experimental infection of pearl gourami Trichogaster leeri and silver gourami T. microlepis with a tissue homogenate of pearl gourami infected by ISKNV induced 70 and $20 \%$ cumulative mortalities in the pearl and silver gourami, respectively.
\end{abstract}

KEY WORDS: Iridovirus · ISKNV · Ornamental fish · Asymptomatic infection · Asian countries

\section{INTRODUCTION}

Iridoviruses have been associated with severe mortality and economic loss in freshwater ornamental fish, including angelfish Pterophyllum scalare, gourami Trichogaster spp., swordtail Xiphophorus hellerii, dwarf gourami Colisa lalia, chromide cichlid Etroplus maculatus, guppy Poecilia reticulata, doctor fish Labroides dimidatus, mollies Poecilia latipinna and African lampeye Aplocheilichthys normani (Armstrong \& Ferguson 1989, Anderson et al. 1993, Hedrick \& McDowell 1995, Rodger et al. 1997, Paperna et al. 2001, Sudthongkong et al. 2002), as well as in a wide variety of marine fish species (Inouye et al. 1992, Bloch \& Larsen 1993, Chua et al. 1994, Matsuoka et al. 1996, Nakajima et al. 1998, Jung \& Oh 2000). Such iridoviruses are becoming ubiquitous due to transfer of ornamental fish by international trade.

In Australia iridovirus-like virions from dwarf gourami Colisa lalia imported from Singapore (Anderson et al. 1993) were reported in 1988, and in 2006 Murray cod iridovirus (MCIV) from intensively farmed Murray cod Maccullochella peelii peelii was observed there (Go et al. 2006); Armstrong \& Ferguson (1989) reported an iridovirus in chromide cichlid Etroplus maculatus in Canada, also imported from Singapore; and Sudthongkong et al. (2002) reported outbreaks of African lampeye Aplocheilichthys normani iridovirus 
(ALIV) and dwarf gourami C. lalia iridovirus (DGIV) in Japan.

Infectious spleen and kidney necrosis virus (ISKNV), recently assigned to the new Megalocytivirus genus of the Iridoviridae family, based on morphological and genetic characteristics (Chinchar et al. 2005), has caused significant economic loss in the mandarinfish Siniperca chuatsi aquaculture sector of China (He et al. 2000). In studies to elucidate the transmission and host range of ISKNV, mandarinfish appears to be the only species infected naturally and the most susceptible species, followed by largemouth bass in experimental infections of 21 fish species tested (He et al. 2002). In addition, the presence of ISKNV has only been reported in China.

Jeong et al. (2006a), using 2-step polymerase chain reation $(\mathrm{PCR})$, reported megalocytivirus in marine fish species that were externally healthy, a condition that could be called persistent or asymptomatic infection. Moreover, investigation of largemouth bass Micropterus salmoides salmoides, using a 1-step PCR technique after the occurrence of mass mortality, has also revealed the long-term persistence of ranavirus, largemouth bass virus (LMBV), in the population (Hanson \& Petrie-Hanson 2001).

Although Megalocytivirus and Ranavirus are epidemiologically and genetically distinct genera in the family Iridoviridae, the data indicated that asymptomatic infections by members of the Iridoviridae family occurred in various fish species. Thus, it is critical to determine whether there is a variant of iridovirus that causes asymptomatic infection or presents a potential risk of mass mortality in ornamental fish in Korea. No previous study has investigated asymptomatic infection by iridoviruses in freshwater ornamental fish species in Korea or other Asian countries.
In the present study the presence of ISKNV in various freshwater ornamental fish species was examined. Thus, attempts were made to (1) confirm natural outbreaks of ISKNV disease by 1-step PCR, (2) survey the prevalence of ISKNV by 2-step PCR in externally healthy fish, (3) analyze the genetic makeup of the ISKNV isolates and to compare them with other iridoviruses, and (4) assess the interspecies infectivity of the various ISKNV isolates.

\section{MATERIALS AND METHODS}

Sampling. Ten freshwater ornamental fish species from wholesalers and importers were sampled and surveyed for iridovirus infection using 2-step PCR analysis with the IK2F/IK2R primer set (Table 1) as described below. In sample processing if any 1 in 3 sampled fish was iridovirus positive, that group was considered an iridovirus positive group. Spleen and kidney tissues from infected samples were collected and stored at $-80^{\circ} \mathrm{C}$ for subsequent analysis. After thawing, fish tissues from the same subset of samples were pooled and homogenized in phosphate-buffered saline (PBS) (0.1 M [pH 7.3]) at a 1:10 (w/v) dilution and then centrifuged at $300 \times g$ for $5 \mathrm{~min}$. After discarding the pellet of cellular debris, the supernatant was centrifuged at $2600 \times g$ for $10 \mathrm{~min}$. The resulting supernatants were used as inocula for the experimental infections.

Iridovirus isolates from ornamental fish. In 2004, 2 iridovirus isolates, pearl gourami iridovirus (PGIV)-1 and PGIV-2, were obtained from 1-step PCR-positive pearl gourami Trichogaster leeri (body weight $4.5 \pm$ $2 \mathrm{~g}$, length $6 \pm 1 \mathrm{~cm}$ ) from Korea. Other viral isolates, PGIV-3 and silver gourami iridovirus (SGIV)-1, were isolated from pearl gourami T. lerri and silver gourami

Table 1. Primers used in the present study

\begin{tabular}{|c|c|c|c|c|c|}
\hline Target & Primer & $\begin{array}{l}\text { Oligonucleotide sequence } \\
\text { (5' to } 3^{\prime} \text { direction) }\end{array}$ & $\begin{array}{l}\text { Expected size } \\
\text { (PCR) }\end{array}$ & $\begin{array}{l}\text { Accession } \\
\text { number }\end{array}$ & Source \\
\hline \multirow[t]{2}{*}{ ATPase gene } & $\begin{array}{l}\text { AT1F } \\
\text { AT1R }\end{array}$ & $\begin{array}{l}\text { CAAACCACAGCGCGGCAAGT } \\
\text { GCCAAGCGGCACATAATT }\end{array}$ & $\begin{array}{c}563 \mathrm{bp} \\
\text { (1-step PCR) }\end{array}$ & \multirow[t]{2}{*}{ AB007367 } & \multirow[t]{2}{*}{ Kurita et al. (1998) } \\
\hline & $\begin{array}{l}\text { AT2F } \\
\text { AT2R }\end{array}$ & $\begin{array}{l}\text { TATAAGCATGTGTGATCCTG } \\
\text { TATAAGCATGTGTGATCCTG }\end{array}$ & $\begin{array}{c}467 \mathrm{bp} \\
\text { (2-step PCR) }\end{array}$ & & \\
\hline \multirow[t]{2}{*}{ MCP gene } & $\begin{array}{l}\text { M1F } \\
\text { M1R }\end{array}$ & $\begin{array}{l}\text { GAGAGACCCCAACACGAC } \\
\text { ACCTGGTGGCTCCAGTGC }\end{array}$ & $\begin{array}{c}1828 \mathrm{bp} \\
\text { (1-step PCR) }\end{array}$ & \multirow[t]{2}{*}{ AF37196 } & \multirow[t]{2}{*}{ He et al. (2001) } \\
\hline & $\begin{array}{l}\text { M2F } \\
\text { M2R }\end{array}$ & $\begin{array}{l}\text { ATAACGACCAGTTCAAAC } \\
\text { GGCGGCGACAATGCCGTG }\end{array}$ & $\begin{array}{c}1220 \mathrm{bp} \\
\text { (2-step PCR) }\end{array}$ & & \\
\hline \multirow[t]{2}{*}{ K2 region } & $\begin{array}{l}\text { IK1F } \\
\text { IK1R }\end{array}$ & $\begin{array}{l}\text { CCTGCATAATACCGATGG } \\
\text { TCTGTCCAATGGCGTAC }\end{array}$ & $\begin{array}{c}2136 \mathrm{bp} \\
\text { (1-step PCR) }\end{array}$ & \multirow[t]{2}{*}{ AY628698 } & \multirow[t]{2}{*}{ Jeong et al. (2006b) } \\
\hline & $\begin{array}{l}\text { IK2F } \\
\text { IK2R }\end{array}$ & $\begin{array}{l}\text { GTGCACAGTCGCAATAC } \\
\text { CCATCTTTATAATAAACCAG }\end{array}$ & $\begin{array}{c}1556 \mathrm{bp} \\
\text { (2-step PCR) }\end{array}$ & & \\
\hline
\end{tabular}


T. microlepis imported from China and Singapore, respectively. Imported fish were immediately transported from the airport to the laboratory. To observe the progress of iridovirus infection, 30 fish that tested positive to 1 -step PCR were kept in a $100 \mathrm{l}$ tank in the laboratory at $26^{\circ} \mathrm{C}$ for $3 \mathrm{wk}$. During this time disease and death due to infection with iridovirus were confirmed using PCR. Iridovirus prevalence in externally healthy fish was determined using 2-step PCR with the IK1F/IK1R and IK2F/IK2R primers.

Isolation of viral nucleic acids. To isolate DNA spleen samples $(20 \mathrm{mg})$ from infected fish were homogenized in $355 \mu \mathrm{l}$ of tris-ethylenediaminetetraacetic acid (TE) buffer (100 mM Tris- $\mathrm{HCl}, 10 \mathrm{mM}$ EDTA, or ethylenediaminetetraacetic acid) and centrifuged at $8000 \times g$ for $10 \mathrm{~min}$. Supernatants were treated with $40 \mu \mathrm{l}$ of $10 \%$ sodium dodecyl sulphate (SDS) and $5 \mu \mathrm{l}$ of $20 \mathrm{mg} \mathrm{ml}^{-1}$ Proteinase K (Roche) for $1 \mathrm{~h}$ at $37^{\circ} \mathrm{C}$. After 3 extractions with phenol-chloroform the DNA was precipitated with ethanol in the presence of $0.3 \mathrm{M}$ sodium acetate, redissolved in $50 \mu \mathrm{l}$ TE buffer and stored at $-80^{\circ} \mathrm{C}$ for later use.

PCR. 1-step PCR was performed in a $50 \mu \mathrm{l}$ reaction mixture containing $0.5 \mu$ l of viral nucleic acid (100 ng of the total nucleic acid extracted from the spleen), $10 \mathrm{mM}$ Tris-HCl (pH 8.3), $50 \mathrm{mM} \mathrm{KCl}, 1.5 \mathrm{mM} \mathrm{MgCl}_{2}$, $0.001 \% \mathrm{w} / \mathrm{v}$ gelatin, $0.5 \%$ Tween-20, $200 \mathrm{M}$ of each dNTP, 1 M of each 1-step PCR primer (Table 1), $1.25 \mathrm{U}$ AmpliTaq DNA polymerase (Perkin-Elmer) with a Perkin-Elmer 2400 thermal cycler. After 2 min of predenaturation at $95^{\circ} \mathrm{C}$, the mixtures were incubated for 30 cycles at $95^{\circ} \mathrm{C}$ for $30 \mathrm{~s}, 55^{\circ} \mathrm{C}$ for $30 \mathrm{~s}$, and $72^{\circ} \mathrm{C}$ for $30 \mathrm{~s}$, followed by an extension period at $72^{\circ} \mathrm{C}$ for $7 \mathrm{~min}$. 2-step PCR was performed under the same conditions as those for 1-step PCR but with $0.5 \mu$ l of the reaction mixture taken from the 1-step PCR procedure as a template and an internal primer set corresponding to the amplicons of the 1-step PCR (Table 1).

Nucleotide sequence determination. The PCR products were purified by agarose gel electrophoresis using a Prep-A-Gene DNA Purification System (BioRad Laboratories) and cloned into the TOPO-TA vector, according to the manufacturer's instructions (Invitrogen). To avoid errors in the PCR process, PCR was repeated twice with the same primers, and each PCR product was cloned and sequenced using the Big Dye Terminator Cycle DNA Sequencing Kit (ABI PRISM, PE Applied Biosystems) and an automatic sequencer. Nucleotide sequences and the deduced amino acid sequences were compared by gene alignment using the MACAW program (Version 2.0.5., National Center for Biotechnology Information, National Institutes of Health).

Experimental infection. For infectivity experiments pearl gourami and silver gourami (body weight 3 to
$5 \mathrm{~g}$, length 6 to $8 \mathrm{~cm}$ ) were obtained from ornamental fish shops. After maintaining them for $3 \mathrm{wk}$ at $26^{\circ} \mathrm{C}$ in 2001 tanks, they were confirmed free of iridovirus using the 2-step PCR. Each of 10 pearl gourami and silver gourami were challenged by an intramuscular injection of $0.1 \mathrm{ml}$ of a $0.45 \mu \mathrm{m}$ (pore size) filtered tissue homogenate $\left(100 \mu \mathrm{g} \mathrm{fish}^{-1}\right)$ prepared from fish infected with PGIV-1 (as described above). Negative control groups of each fish species were shaminoculated by an intramuscular injection of $0.1 \mathrm{ml}$ sterile PBS ( $\mathrm{pH}$ 7.2). After injection all fish were maintained at $26^{\circ} \mathrm{C}$ in $20 \mathrm{l}$ aquaria, and the water was changed daily for $3 \mathrm{wk}$. Any dead fish were collected on a daily basis, and iridovirus infection was confirmed by PCR using the IK2F/IK2R primer set (Table 1) and by examining spleen imprints for the presence of enlarged cells using light microscopy.

Nucleotide sequence accession number. Determined nucleotide sequences of the open reading frame (ORF)-2 region (Jeong et al. 2006b) of SGIV-1 and PGIV-3 have been submitted to GenBank (accession no. DQ812903 and DQ812904, respectively).

\section{RESULTS}

\section{Iridovirus infection}

Of 88 individual fish representing 10 freshwater ornamental fish species, 17 and 54 tested positive for iridovirus by 1-step PCR and 2-step PCR, respectively (Table 2). Only 3 species were 1-step PCR positive, with the following incidence rates: pearl gourami (36\%), dwarf gourami (25\%) and silver gourami (8\%). All these 1-step PCR positive species had mortality rates during the $3 \mathrm{wk}$ holding period (at $26^{\circ} \mathrm{C}$ ) of 20 to $60 \%$ and showed histopathological lesions typical of iridovirus infection (data not shown). None of the ornamental fish species analyzed in the present study were free of iridovirus using the 2-step PCR. Although the sample sizes examined were relatively small, the incidence of iridovirus infection did not seem to be influenced by seasonal or geographical differences because similar incidences of infection were found in fish collected during different seasons and from different geographic areas (i.e. Korea, Singapore and China; see Table 3).

\section{DNA nucleotide sequences of isolated iridoviruses}

The nucleotide sequences of the PCR amplicons, using AT2F/AT2R and M2F/M2R primers that targeted the the adenosine triphosphatase (ATPase) and major capsid protein (MCP) genes for the iridoviruses PGIV- 
1, $-2,-3$, and SGIV-1, appeared to be the same as that of ISKNV isolated from mandarinfish (He et al. 2001; GenBank accession no. AF371960). In addition, the PGIVA and PGIV-B of externally healthy fish, detected by 2-step PCR, appeared to have the same nucleotide sequences. Interestingly, 3 different lengths of amplicon were revealed by the 2-step PCR with the IK2F/IK2R primer designed from the K2 region known to contain many internal repetitive sequences (Jeong et al. 2006b) (Figs. 1 \& 2). The longest amplicon, 1398 $\mathrm{bp}$, was produced with the template nucleic acid of SGIV-1 isolated from 1 sample of silver gourami imported from Singapore (Lane 7 of Fig. 1). It was $380 \mathrm{bp}$ longer than that of ISKNV. A section of $1357 \mathrm{bp}$ was produced with the template nucleic acid of PGIV-3 isolated from pearl gourami imported from China (Lane 8 of Fig. 1). Both PGIV-1 and PGIV-2, isolated from pearl gourami obtained in Korea, produced the same size of amplicon as that of ISKNV. Moreover, PGIV-A and PGIV-B amplicons produced from externally healthy pearl gourami (positive only in 2-step PCR) were also the same as that of PGIV-1 (Figs. 1 \& 2). Different lengths of amplicons were derived from the insertion

Table 2. Prevalence of iridoviruses in 10 ornamental fish species in Korea in 2004

\begin{tabular}{|lccc|}
\hline Fish species & No. of fish & $\begin{array}{c}\text { 1-step PCR } \\
\text { positive (\%) }\end{array}$ & $\begin{array}{c}\text { 2-step PCR } \\
\text { positive (\%) }\end{array}$ \\
\hline $\begin{array}{l}\text { Pearl gourami } \\
\text { Trichogaster leeri }\end{array}$ & 36 & $13(36)$ & $20(56)$ \\
$\begin{array}{l}\text { Silver gourami } \\
\text { T. microlepis }\end{array}$ & 13 & $1(8)$ & $10(77)$ \\
$\begin{array}{l}\text { Dwarf gourami } \\
\text { Colisa lalia }\end{array}$ & 12 & $3(25)$ & $8(67)$ \\
$\begin{array}{l}\text { Platy } \\
\quad \text { Xiphophorus maculatus }\end{array}$ & 6 & 0 & $5(83)$ \\
$\begin{array}{l}\text { Molli } \\
\text { Poecilia sphenopsx }\end{array}$ & 4 & 0 & $4(100)$ \\
$\begin{array}{l}\text { Guppy } \\
\text { Lebistes reticulatus }\end{array}$ & 3 & 0 & $2(67)$ \\
$\begin{array}{l}\text { Oscar } \\
\text { Astronotus ocellatus }\end{array}$ & 2 & 0 & $2(100)$ \\
$\begin{array}{l}\text { Neontetra } \\
\text { Hyphessobrycon innesi }\end{array}$ & 2 & 0 & $1(50)$ \\
$\begin{array}{l}\text { Angelfish } \\
\text { Pterophyllum eimekei }\end{array}$ & 7 & 0 & $1(14)$ \\
$\begin{array}{l}\text { Swordtail } \\
\text { X. helleri }\end{array}$ & 3 & 0 & $1(33)$ \\
$\begin{array}{l}\text { Total } \\
\quad\end{array}$ & 88 & $17(19)$ & $54(61)$ \\
\hline
\end{tabular}

(or deletion) of repetitive sequences present in the K2 region. No substitutions were found in the analyzed regions of the $\mathrm{K} 2$ region in the isolated iridoviruses. After cloning, determined nucleotide sequences were submitted to GenBank and assigned accession numbers DQ812903 and DQ812904 for SGIV-1 and PGIV-3, respectively.

\section{Pathogenicity of PGIV-1}

Pearl and silver gourami were challenged with PGIV-1 (derived from infected spleen homogenate, $10 \mu \mathrm{g} \mathrm{g}^{-1}$ body $\mathrm{wt}$ ) to examine mortality rates (Fig. 3). Infection with PGIV-1 led to 70 and $20 \%$ cumulative mortality within $3 \mathrm{wk}$ after challenge in pearl and silver gourami, respectively. No fish in the negative control groups injected with PBS died. Infections of PGIV-1 in both species were confirmed by PCR with the IK2F/IK2R primer set and the presence of histopathological lesions, which included hypertrophic cells in enlarged spleens.

\section{DISCUSSION}

It has been reported that mandarinfish Siniperca chuatsi is the only species affected in natural outbreaks of the ISKNV (He et al. 2002). However, iridoviral DNA sequences, MCIV, were detected in paraffin-embedded tissues from Murray cod Maccullochella peelii peelii that died during epizootics in Australia (Go et al. 2006). It has also been confirmed that Murray cod are highly susceptible to a megalocytivirus of DGIV that has been found in southeast Asia (Go \& Whittington 2006). Both iridoviruses are very closely related at the nucleotide level to ISKNV and should be considered to be 


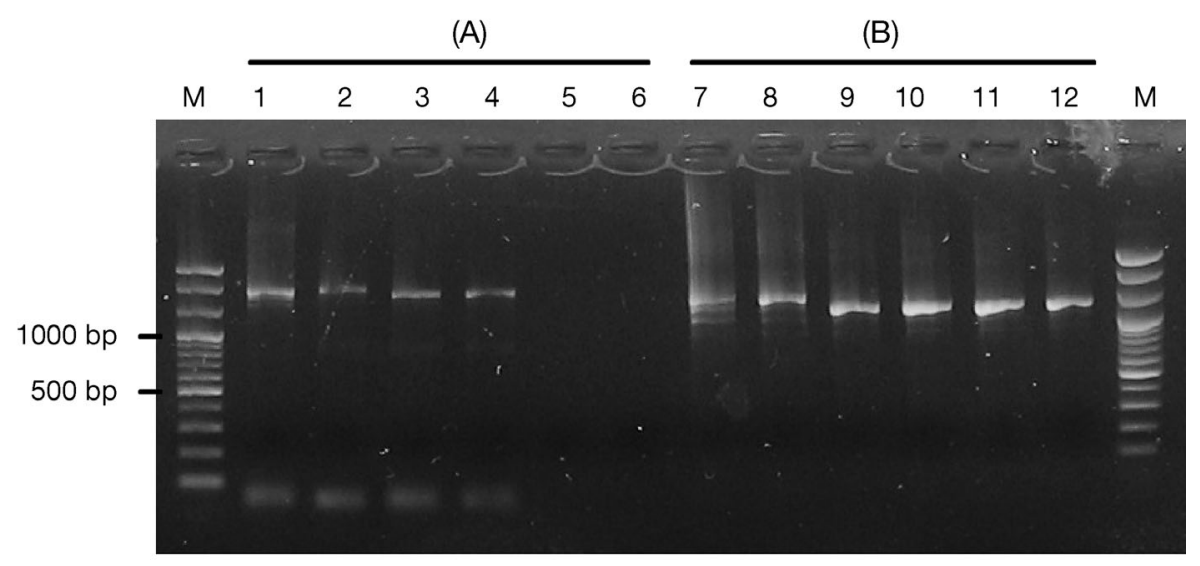

Fig. 1. Amplification of DNA isolated from freshwater ornamental fish infected by iridovirus, symptomatically (PGIV-1/-2/ -3/SGIV-1) and asymptomatically (PGIV-A/-B) using (A) 1-step PCR with IK1F/IK1R and (B) 2-step PCR with IK2F/IK2R. Total nucleic acid was isolated from silver gourami iridovirus (SGIV)-1 from Singapore (Lane 1 and 7), pearl gourami iridovirus (PGIV)3 from China (Lane 2 and 8), PGIV-1 from Korea (Lane 3 and 9), PGIV-2 from Korea (Lane 4 and 10), PGIV-A from Korea (Lane 5 and 11), PGIV-B from China (Lane 6 and 12). Other iridoviruses from freshwater ornamental fish from the present study produced the same size of amplicons as that of PGIV-1; M: 100 bp DNA ladder

minor variants or strains of the same species rather than distinct species within the Megalocytivirus genus. Such findings may imply that ornamental fish species are susceptible to various megalocytiviruses. In the present study we report the results of natural infection of the ISKNV, both clinical (19\%) and asymptomatic $(61 \%)$, in 10 freshwater ornamental fish species in Korea. Clinical ISKNV infection occurred naturally in 3 species, pearl, dwarf and silver gourami, either cultured in Korea or imported to Korea from Singapore/ China, and was confirmed by 1-step PCR and observation of histopathological lesions. With no exceptions these groups showed high mortality during a period of 3 wk maintenance in laboratory aquaria. In contrast, the other 7 fish species, positive in 2-step PCR only and externally healthy, did not show clinical signs of infection nor mortality during the same maintenance period. It should be noted that examination of additional, larger samples may reveal fish species other than those found in the present study with symptomatic or asymptomatic iridoviral infections.

Our 1-step PCR results yielded sequences of the ATPase and MCP genes that are completely consistent with those of ISKNV (GenBank accession no. AF371960), indicating that ISKNV disease occurs in ornamental freshwater fish from Asian countries including Korea. In addition, no differences were found between the nucleotide sequences of the iridoviruses in fish infected clinically or asymptomatically. These findings suggest a potential risk of ISKNV disease in various freshwater ornamental fish species, including the 7 species that were 1-step PCR negative, in which clinical signs and mortality were not observed.
Jeong et al. (2006b) reported many different types of repetitive sequences in the genome of iridoviruses isolated from marine fish, especially as a cluster form in the 3 ' terminal region of the ORF-2 gene of the K2 region. Such repetitive sequences might be variable in individual fish or depend on the iridovirus strain as those found in the ORF-1 gene (Jeong et al. 2006a). Thus, we performed another PCR with ORF-2-specific primers to compare the genetic variation in ISKNVs isolated from 1-step PCR positive fish using ATPasespecific primers. Interestingly, amplicon sizes were different, and SGIV-1 was longer than PGIV-3, which was longer than ISKNV. No substitutions or frame shifting of the ORF-2 gene were found compared to that of ISKNV (Fig. 2), but deletions/insertions of $42 \mathrm{bp}$ and 339 bp repetitive sequences caused size variation among the amplicons. In addition, the nucleotide sequences of both PGIV-A and PGIV-B, obtained from externally healthy fish that were 2-step PCR positive with ORF-2-specific primers (Fig. 1), appeared to be the same as that of PGIV-1 (Fig. 2). It can only be assumed that the repetitive sequences might be associated with important regulatory functions during viral replication (He et al. 2001, Jancovich et al. 2003).

Different cumulative mortalities, dependent on the host fish species infected with red sea bream iridovirus (RSIV), have been reported for various marine fish species (Nakajima \& Maeno 1998, Sano et al. 2001). In the present study pearl gourami and silver gourami were susceptible to PGIV-1 isolated from pearl gourami and resulted in different cumulative mortalities (Fig. 3). Because these viruses are difficult to cultivate in fish cell lines (Nakajima \& Sorimachi 1994, Chou et al. 1998, Wang et al. 2003), the virus susceptibility experiments 
1 KKT TTT TVATTTYAPTEPEEPEEEEDEYDCPEYEDI TSAPPT TTPPPKRECKKKKRKPE

2 KKT TTT TVA TTTYAPTEPEEPEEEEDEYDCPEYEDI TSAPPT TTPPPKRECKKKPKP

3 KKT TTT TVATTTYAPTEPEEPEEEEDEYDCPEYEDI TSAPPT TTPPPKRECKKKPKP

240

1 PERAPPPAAASHRPPA I QNEYPUY KQSTGEEDDYHLGDI GGM KKGGLLLG I Y IGSCMYAAAFI MFA I IGHLFFRFTRCGO

2 PERAPPPAAASHRPPA IQNEYPYYKQSTGEEDDYHLGD I GGMKKGGLLMGI Y IGSCM YAAAFI MFA I IGHLFFRFTRCGO

3 PERAPPPAAASHRPPAI QNEYPYYKOSTGEEDDYHLGDI GGMKKGGLLMGI Y IGSCMYAAAAFI MFA I IGHLFFRFTRCGQ

400

Fig. 2. Comparative analysis of the open reading frame (ORF)-2 amino acid sequences of the K2 region (Jeong et al. 2006b) of iridoviruses isolated from freshwater ornamental fish. Gaps are represented as dashes. Two different repeating sequences involving insertion/deletion are shown as light and dark gray boxes, respectively. 1, 2 and 3: silver gourami iridovirus (SGIV)-1, pearl gourami iridovirus (PGIV)-3 and other iridoviruses from freshwater ornamental fish from the present study including PGIV-1/-2/

-A/-B/infectious spleen and kidney necrosis virus (ISKNV) produced the same size of amplicons as that of PGIV-1

could only be performed using viruses derived from tissues of infected fish. After being challenged with PGIV-1, isolated viruses from dead fish of the 2 gourami species produced the same size amplicon and nucleotide

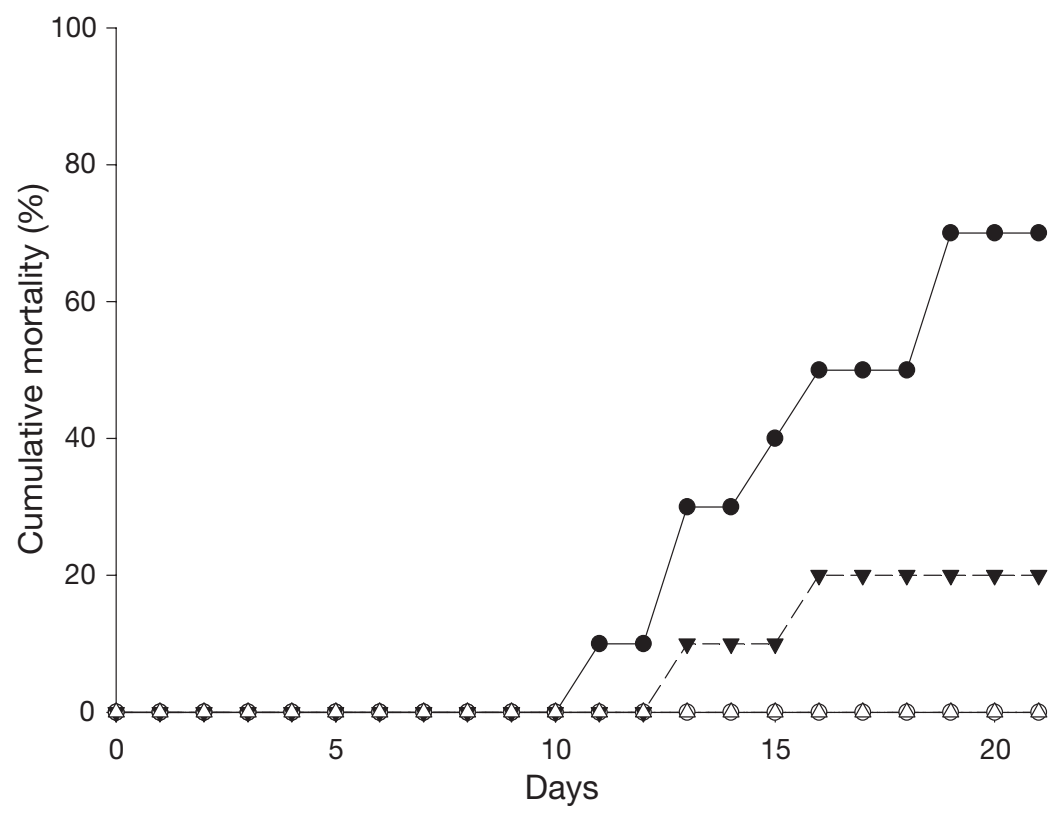

Fig. 3. Trichogaster leeri and T. microlepis. Cumulative mortality of pearl gourami and silver gourami after intramuscular injection of homogenate of the spleen infected with pearl gourami iridovirus (PGIV)-1. •: Pearl gourami;

$\mathbf{\nabla}$ : silver gourami; O: control pearl gourami and $\Delta$ : control silver gourami sequence (data not shown) of PCR-amplified DNA as those of the PGIV-1 used as the inoculum, indicating that the iridovirus genome was not restricted by host species, in agreement with previous studies (Jeong et al. 2003).

Recently, it has been found that there is a high frequency of asymptomatic iridoviral infections, demonstrated by 2step PCR analysis, in various marine fish species in Korea (Jeong et al. 2006a). Although such asymptomatic infections in fish by iridoviruses have also been reported for LMBV in wild largemouth bass (Hanson \& Petrie-Hanson 2001), the present study is the first report of (1) the occurrence of natural ISKNV disease outbreaks in 3 different species of cultured ornamental fish, and (2) the presence of asymptomatic ISKNV infection in various ornamental fish species demonstrated by 2-step PCR. In addition, it should be noted that all parent fish in ornamental farms of Korea have been imported from Asian countries including Singapore. Thus, samples of 2-step PCR positive found in pearl gourami hatched in Korea as well as imported from Asian countries (Table 3) may suggest the possibility of vertical transmission of iridovirus. Fur- 
ther studies are needed to determine the potential risk of ISKNV in other fish species important to aquaculture industries.

Acknowledgements. This work was supported by Korea Research Foundation Grant (KRF-2005-041-F00058).

\section{LITERATURE CITED}

Anderson IG, Prior HC, Rodwell BJ, Harris GO (1993) Iridovirus-like virions in imported dwarf gourami Colisa lalia with systemic amoebiasis. Aust Vet J 70:66-67

Armstrong RD, Ferguson HW (1989) Systemic viral disease of the chromide cichlid Etroplus maculatus. Dis Aquat Org 7:155-157

Bloch B, Larsen JL (1993) An iridovirus-like agent associated with systemic infection in cultured turbot Scophthalmus maximus fry in Denmark. Dis Aquat Org 15:235-240

Chinchar G, Essbauer S, He JG, Hyatt A, Miyazaki T (2005) Family iridoviridae. In: Fauquet CM, Mayo MA, Maniloff J, Desselberger U, Ball LA (eds) Virus taxonomy: classification and nomenclature of viruses. Eighth report of the International Committee on the Taxonomy of Viruses. Academic Press, San Diego, CA, p 145-161

Chou HY, Hsu CC, Peng TY (1998) Isolation and characterization of a pathogenic iridovirus from cultured grouper Epinephelus sp. in Taiwan. Fish Pathol 33:201-206

Chua FHC, Ng ML, Ng KL, Loo JJ, Wee JY (1994) Investigation of outbreaks of a novel disease, 'sleepy grouper disease', affecting the brown-spotted grouper, Epinephelus tauvina Forskal. J Fish Dis 17:417-427

Go J, Whittington R (2006) Experimental transmission and virulence of a megalocytivirus Iridoviridae of drawf gourami Colisa lalia from Asia in Murray cod Maccullochella peelii peelii in Australia. Aquaculture 258:140-149

Go J, Lancaster M, Deece K, Dhungyel O, Whittington R (2006) The molecular epidemiology of iridovirus in Murray cod Maccullochella peelii peelii and dwarf gourami Colisa lalia from distant biogeographical regions suggests a link between trade in ornamental fish and emerging iridoviral diseases. Mol Cell Probes 20:212-222

Hanson LA, Petrie-Hanson L (2001) Persistence of largemouth bass virus infection in a northern Mississippi reservoir after a die-off. J Aquat Anim Health 13:27-34

He JG, Wang SP, Zeng K, Huang ZJ, Chan SM (2000) Systemic disease caused by an iridovirus-like agent in cultured mandarinfish Siniperca chuatsi (Basilewsky), in China. J Fish Dis 23:219-222

He JG, Deng M, Weng SP, Li Z and others (2001) Complete genome analysis of the mandarinfish infectious spleen and kidney necrosis iridovirus. Virology 291:126-139

He JG, Zeng K, Weng SP, Chan SM (2002) Experimental transmission, pathogenicity and physical-chemical properties of infectious spleen and kidney necrosis virus (ISKNV). Aquaculture 204:11-24

Editorial responsibility: Mark Crane, Geelong, Victoria, Australia
Hedrick RP, McDowell TS (1995) Properties of iridoviruses from ornamental fish. Vet Res 26:423-427

Inouye K, Yamano K, Maeno Y, Nakajima K, Matsuoka M, Wada Y, Sorimachi M (1992) Iridovirus infection of cultured red sea bream Pagrus major. Fish Pathol 27:19-27 (in Japanese with English Abstract)

Jancovich JK, Mao J, Chinchar VG, Wyatt C and others (2003) Genomic sequence of a ranavirus Iridoviridae associated with salamander mortalities in North America. Virology 316:90-103

Jeong JB, Jun LJ, Yoo MH, Kim MS, Komisar JL, Jeong HD (2003) Characterization of the DNA nucleotide sequences in the genome of red sea bream iridoviruses isolated in Korea. Aquaculture 220:119-133

Jeong JB, Jun LJ, Park KY, Kim KH, Chung JK, Komisar JL, Jeong HD (2006a) Asymptomatic iridovirus infection in various marine fishes detected by a 2-step PCR method. Aquaculture 255:30-38

Jeong JB, Kim HY, Kim KH, Chung JK, Komisar JL, Jeong HD (2006b) Molecular comparison of iridoviruses isolated from marine fish cultured in Korea and imported from China. Aquaculture 255:105-116

> Jung SJ, Oh MJ (2000) Iridovirus-like infection associated with high mortalities of striped beakperch Oplegnathus fasciatus (Temminck et Schlegel) in southern coastal areas of the Korean Peninsula. J Fish Dis 23:223-226

Kurita J, Nakajima K, Hirono I, Aoki T (1998) Polymerase chain reaction (PCR) amplification of DNA of red sea bream iridovirus (RSIV). Fish Pathol 33:17-23

Matsuoka S, Inouye K, Nakajima K (1996) Cultured fish species affected by red sea bream iridoviral disease from 1991 to 1995. Fish Pathol 31:233-234 (in Japanese with English Abstract)

Nakajima K, Maeno Y (1998) Pathogenicity of red sea bream iridovirus and other fish iridoviruses to red sea bream. Fish Pathol 33:143-144

Nakajima K, Sorimachi M (1994) Biological and physicochemical properties of the iridovirus isolated from cultured red sea bream Pagrus major. Fish Pathol 29:29-33

Nakajima K, Inouye K, Sorimachi M (1998) Viral diseases in cultured marine fish in Japan. Fish Pathol 33:181-188

Paperna I, Vilenkin M, de Matos AP (2001) Iridovirus infections in farm-reared tropical ornamental fish. Dis Aquat Org 48:17-25

Rodger HD, Kobs M, Macartney A, Frerichs GN (1997) Systemic iridovirus infection in freshwater angelfish Pterophyllum scalare (Liechtenstein). J Fish Dis 20:69-72

Sano M, Minagawa M, Sugiyama A, Nakajima K (2001) Susceptibility of fish cultured in subtropical area of Japan to red sea bream iridovirus. Fish Pathol 36:38-39

Sudthongkong C, Miyata M, Miyazaki T (2002) Iridovirus disease in two ornamental tropical freshwater fishes: African lampeye and dwarf gourami. Dis Aquat Org 48:163-173

Wang CS, Shih HH, Ku CC, Chen SN (2003) Studies on epizootic iridovirus infection among red sea bream Pagrus major (Temminck \& Schlegel) cultured in Taiwan. J Fish Dis 26:127-133

Submitted: February 2, 2007; Accepted: November 7, 2007 Proofs received from author(s): January 11, 2008 